\title{
Muhasebe ve Simülasyon Kuramı İlişkisi
}

\author{
DOI: 10.26466/opus.461551
}

\begin{abstract}
$\underline{\text { Ömer Yazan }}^{*}$
* Dr. Öğr. Üyesi, Aksaray Üniversitesi, İktisadi ve İdari Bilimler Fakültesi, Aksaray / Türkiye E-Posta: omer yazan@hotmail.com ORCID: $\underline{0000-0001-8680-3442}$
\end{abstract}

Öz

Jean Baudrillard'ın Simülasyon Kuramı, gerçeğin modeller aracıllğıyla türetilmesini simülasyon ve simülasyon evreninde gerçeklik olarak nitelenen görünümleri ise simülakrlar olarak tanımlamaktadır. Muhasebe, somut gerçeklikleri temsil etmek amactyla geliştirdiği ancak kendi gerçeklikleri olarak sunduğu hesaplar ve mali tablolar gibi imgelerle ekonomik kararlarında işletme faaliyetlerinden doğrudan veya dolayl olarak etkilenen bireyler ve kurumlar için bir bilgi ve karar kaynağıdır. $B u$ bağlamda simülasyon ve simülakrlar ile muhasebenin temel varsayım ve uygulamaları arasında bir ilişki öngörülebilir. Bu çalışmada söz konusu ilişki Kişilik ve Iş̧letmenin Sürekliliği varsayımla$r l$, senetli ve senetsiz alacaklar, reeskont işlemleri, yabancı paralı işlemlerin dönem sonu değerlemeleri, karşılıklar, gelir ve gider tahakkuklarl, amortisman işlemleri, menkul kıymetler, türev finansal ürünler, finansal araçların gerçeğe uygun değerle ölçümü, kripto para birimleri, sürdürülebilirlik ve kurumsal sosyal sorumluluk raporları ve denetim skandalları örnekleri üzerinden değerlendirilmiştir. Bu yönüyle çalışma, Simülasyon Kuramı ile muhasebe arasındaki olası ilişkiye bütünsel bir yaklaşım getirme iddiasındadır.

Anahtar Kelimeler: Muhasebe, Simülasyon Kuramı, Simülasyon, Simülakr.

OPUS (c) Uluslararası Toplum Araştırmaları Dergisi-International Journal of Society Researches ISSN:2528-9527 E-ISSN : 2528-9535

http://opusjournal.net 


\title{
The Relation with Accounting and Simulation Theory
}

\begin{abstract}
Jean Baudrillard's Simulation Theory describes simulation as to derive real by way of models, and simulacras as appearances that are characterized with reality in the simulation universe. Accounting is a source of knowledge and decision for individuals and institutions that are effected from business' activities directly or indirectly in their economic decisions, with images as accounts and financial statements that are developed with the aim of represent tangible realities but are presented as accounting's own realities. Within this context, a relation can be projected between simulations and simulacras with accounting's basic assumptions and implementations. In this study, the relevant relation has been evaluated by samples as the assumptions of Economic Entity and Going Concern, accounts receivable and bills receivable, rediscount operations, year-end valuation of operations with foreign currency, provisions, accrued income and expenses, depreciation operations, securities, derivative financial instruments, measurement of financial instrument with fair value, crypto currencies, sustainability and corporate social responsibility reports and auditing scandals. With this aspect, the study aims to provide a total approach to the relationship between Simulation Theory and accounting.
\end{abstract}

Keywords: Accounting, Simulation Theory, Simulation and Simulacra.

OPUS (c) Uluslararası Toplum Araştırmaları Dergisi-International Journal of Society Researches ISSN:2528-9527 E-ISSN : 2528-9535

http://opusjournal.net 


\section{Giriş}

Jean Baudrillard'ın "Simülasyon Kuramı1" 20.yy.'da insanî bilimler alanında ortaya atılmış en önemli kuramlardan biri olarak değerlendirilmektedir. Bu kuramda Baudrillard (2014, s.13-14), bir köken ya da bir gerçeklikten yoksun olan gerçeğin modeller aracılığıyla türetilmesini hipergerçek yani simülasyon olarak tanımlamıştır. Simülasyonlardan oluşan bir evrende gerçeklik şeklinde kabul edilen görünümleri ise simülakr olarak nitelendirmiştir². Baudrillard'ın simülasyon tanımlaması, kavramın mevcut bir gerçekliğin tüm durum ve şartlarıyla taklit edilmesi şeklindeki yaygın bilinen karşılığından oldukça farklıdır. Zira söz konusu kuram, simülasyonu mevcut bir gerçekliği taklit etmekten ziyade aslının yerini almış ve asıl olarak kabul edilmiş yapay bir gerçeklik olarak tanımlamaktadır.

Baudrillard'ın Simülasyon Kuramı ile insan yaşamı ve eylemlerinin hemen her yönü arasında doğrudan veya dolaylı olarak ilişki kurulabilir. Bu ilişki muhasebe için de öngörülebilir niteliktedir. Nitekim muhasebe literatüründe simülasyon, simülakrlar ve muhasebe ilişkisini irdelemiş çeşitli çalışmalar bulunmaktadır. Macintosh, Shearer, Thornton ve Welker (2000), Macintosh (2002) ve Gårseth-Nesbakk (2011) çalışmalarında simülasyon, simülakrlar ve muhasebe bilgileri arasındaki ilişkiyi incelemişlerdir. Bougen ve Young (2012), finansal araçların gerçeğe uygun değerle ölçüm ve değerlemelerini simülakr ve simülasyon bağlaminda irdelemişlerdir. Anwar ve Suryaningrum (2013), muhasebede simülakr olarak şerefiye işlemlerini değerlendirirken Boiral (2013) GRI bazlı sürdürülebilirlik raporlarını bir tür simülakr olarak ele almıştır. Benzer bir biçimde Corazza ve diğerleri (2017), sürdürülebilirlik raporlarında sunu-

\footnotetext{
${ }^{1}$ Kuram, Baudrillard'ın takipçileri tarafından Simülasyon Kuramı şeklinde nitelendirilmiş ve bu niteleme yaygınlaşmış olmakla birlikte Baudrillard tarafından "Kuramsal Şiddet" olarak adlandırmıştır.

2 Gerçeklik ve simülakr ilişkisi Jowett (1941)'in çalışmasında Platon'un Mağara Alegorisi ile ilişkilendirilmiştir (Corazza ve diğerleri 2017, 415). Alegori'de mağaradaki bireyler sadece gerçek varlıkların yansımalarını algılayabildiklerinden bu yansıları hakikat olarak kabul etmektedirler. Bununla birlikte bir şekilde mağaradan çıkarak yansıların kaynağı olan nesneleri görebilmiş bir bireyin geriye kalanlara hakikatı anlatması ve ona doğru yönlendirme çabası söz konusudur. Simülasyon Kuramı'nda ise simülasyon hakikatın yerine geçmiş olup sorgulanmamaktadır. Bu yönüyle Mağara Alegorisi, Simülasyon Kuramı'nı tam olarak açıklayamayacaktır.
} 
lan ortak değer yaratma açılamalarını bir tür simülakr olarak incelemişlerdir.

İlgili literatür muhasebe, simülasyon ve simülakr ilişkisini genellikle spesifik konular üzerinden değerlendirmektedir. Bu çalışmada ise Baudrillard'ın Simülasyon Kuramı'nın temel dinamikleri baz alınarak konu, muhasebenin teorik temelleri, temel varsayımları, muhasebe uygulamaları, raporlama ve denetim konuları ile ilişkilendirilmektedir. Bu yönüyle çalışmada bütünsel bir bakış açısı geliştirilmeye çalışılarak muhasebe uygulamalarının ilgili kuramla bağlantısı çeşitli örnekler üzerinden irdelenmektedir.

\section{Simülasyon Kuramı́na İlişkin Temel Tanımlamalar}

Baudrillard'ın Simülasyon Kuramı'na göre simülasyon, günümüzde hakikat ilkesinin yerini almış olup kendi yapay gerçekliklerine (simülakrlara) sahiptir. Gerçek bir olguyla karşılaşıldığında ne tür fiziki veya sosyal tepkiler veriliyor, davranış kalıpları geliştiriliyorsa simüle edilen olguda da aynısı yapılmaktadır. Örneğin bir hastalığın simüle edilmesinde kişi bir yatağa uzanıp insanları hasta olduğuna inandırmaya çalışmamakta, hastalığa ait çeşitli semptomları göstermektedir. Bu örnek, simülasyonun gerçekle sahte, düşsel veya yapay olan arasındaki farkı ortadan kaldırmakta olduğunu göstermektedir. (Baudrillard, 2014, s.1416).

Baudrillard (2014, s.33) simülasyonun en belirgin özelliğini “...en önemsiz olguları bile kapsayan gerçeğin yerini almış modellerden oluşması..." şeklinde tanımlamaktadır. Bu sebeple simülasyonun her zaman gerçekten daha etkili olduğu değerlendirilmiştir (Baudrillard, 2014, s.83). Nitekim simülakrlar, bir simülasyon evreninde gerçeğin/asılın yerini alan görünümler olarak sadece kendi kendinin yerine geçen bir olguya dönüşmüş olmaktadır (Baudrillard, 2014, s. 18). Bu yönüyle simülasyonun gerçeklikleri yani simülakrlar, sadece sunulduğu kadarıly bilinecek ve onunla yetinileceğinden insanın bilme arzusuna da sınır çekildiği ifade edilmektedir (Güzel, 2015, s.73).

Baudrillard (2011, s.87) tarihi gelişimi içinde Simülakrlar Düzeni'ni üç basamaklı olarak ele almaktadır. Birinci basamakta Rönesans'tan Sanayi Devrimi'ne kadar süren kopyalama düzeni, ikinci basamakta sanayileşme 
döneminin egemen düzeni olan üretim, üçüncü basamakta ise kodların belirleyici olduğu simülasyon düzeni yer almaktadır. Rönesans'tan sanayi devrimine uzanan süreç, sahte ve asılın bir arada sunulduğu, dünyanın özellikle heykel, resim, mimari gibi alanlarda- ideal bir kopyasının çıkarılmaya çalışıldığı bir dönemi ifade etmektedir. Ancak bu dönemde kopyalama töz ${ }^{3}$ ve biçimle ilişkili olup ilişkiler ve yapılardan uzaktır. Sanayi devrimi sonrası kopya, sonsuz kez çoğaltılabilen bir üretim sürecinin temel nesnesine dönüşmüş, kopyaların ayırt edici özellikler taşımaları değil bir diğeriyle aynı olmaları esas alınmıştır. Seri üretim sonucu üretilen nesneler birbirlerinin sonsuz sayıdaki simülakrına dönüşmektedir. $\mathrm{Bu}$ aşamada enerji ve güce dayalı makinelerle somutlaşmış üretici ve üretken simülakrlardan da söz edilmektedir. Simülakr düzeninin son basamağında ise elektronik kodların gerçekliğin ölçütlerine tamamen hakim olduğu bir simülasyon evresi, mutlak bir denetimi hedefleyen simülasyon simülakrları söz konusudur (Baudrillard, 2011, s.87-101; Baudrillard, 2014, s.158).

Baudrillard'ın Simülasyon Kuramı'nın, modern topluma, toplumsal ilişkilere, algı yapılarına ve bireylerin karar alım süreçlerine karşı geliştirilen en önemli eleştirilerden biri olduğu belirtilebilir. Zira hakikat olarak algılanan ve aksinin sorgulanmasına ihtiyaç duyulmayan simülasyon evreninin yapay gerçeklikleri/simülakrlar, modern toplumu yönlendiren temel dinamikler olarak açığa çıkmaktadır.

Baudrillard'ın simülasyon düzeni bir tür toplumsal evrimin son basamağı olarak kurgulanmıştır. Kuram, gerçeklik evrenini tüketip simülasyon evrenine geçmiş bir dünya için geliştirilmiştir. Ancak farklı toplumların değişim ve dönüşümünün eş güdümlü olmadığ1 açıktır. Bu yönüyle Türk toplumunun henüz gerçeklik evrenini dahi tam olarak tamamlayamadığı, simülasyon evrenine geçmekten uzak bir konumda bulunduğu değerlendirilmektedir (Güzel, 2015, s.66). Bununla birlikte bu çalışmanın amacı Türk toplumunda muhasebe algısının değerlendirilmesi, kültürel veya sosyolojik farklılıkların muhasebe ile ilişkisi veya etkileşimini ele almak değildir. Nitekim mevcut Tekdüzen Hesap Planı ve muhasebe düzeni ile Türkiye Muhasebe ve Finansal Raporlama Stan-

3 Töz: Değişenlerin özünde değişmeden kaldığı varsayılan idealist kavram (http://www.tdk.gov.tr/index.php?option=com_gts\&arama=gts\&kelime $=t \% C 3 \% B 6 z \& u i d=52302 \&$ guid $=T$ DK.GTS.5874ea13dc9d93.18916879). 
dartları hükümleri bu topluma özgü nitelikler barındırmaktan ziyade uluslararası karşılaştırılabilirlik boyutuyla değerlendirilebilecektir. Öyle ki çalışma temel vurgusu itibariyle muhasebe ve Simülasyon Kuramı arasındaki bağıntıyı sorgulamakta olup meta-teorik bir nitelikte kurgulanmiştır.

Simülasyonun hâkim olduğu bir toplumda birey imgelerden oluşan bir evrende yaşamayı kabullenmiş olup gerçeklikle ilişkili olan her unsuru da yine bu imgeler üzerinden değerlendirmektedir (Güzel, 2015, s.7071). Muhasebe, somut gerçeklikleri temsil etmek amaciyla geliştirdiği ve kendi gerçeklikleri olarak sunduğu hesaplar ve mali tablolar gibi imgelerle ekonomik kararlarında işletme faaliyetlerinden doğrudan veya dolaylı olarak etkilenen bireyler ve kurumlar için bir bilgi ve karar kaynağı teşkil etmektedir. Nitekim muhasebe, iktisadi ve ticari olarak anlaşllır bir mantığa sahip olmakla birlikte somut gerçeklikle doğrudan desteklenmeyen ancak gerçeklik olarak kabul edilen ve tüm süreçlerin bu kabule göre işletildiği bazı teorik temellere ve uygulamalara sahiptir. Çalışmanın takip eden bölümlerinde bu unsurlar Baudrillard'ın Simülasyon Kuramı ile ilişkilendirilerek ele alınmıştır.

\section{Muhasebe, Simülasyon ve Simülakrlar}

Baudrillard (2011, s.87) simülakr düzenini tarihsel sürecine göre kopyala$m a$, üretim ve simülasyon düzeni şeklinde ele almıştır. Söz konusu simülakr düzeninin basamakları muhasebenin tarihsel dönüşüm süreci içinde de karşılık bulabilir. Öyle ki modern muhasebenin temelini oluşturan çift yanlı kayıt yönteminin kullanım örneklerinin yaygınlaşması, zamansal olarak kopyalama evresinin hakim olduğu Rönesans dönemiyle örtüşmektedir. Ticari ilişkiler ve değer değişimleri muhasebe hesapları ve mali tablolar üzerinden kopyalanmakta, gerçek ilişkiler yapay kişilik sahibi muhasebe hesapları üzerinden temsil edilerek kaydedilmektedir. Ancak bu dönemde çift yanlı kayıt yöntemi, birbirinden farklı hesap, kayıt ve raporlama mantığı ile uygulanmıştır. Dolayısıyla kopyanın "seri üretimi" henüz söz konusu değildir. Simülakrların üretim evresi olan Sanayi devrimi ve takip eden dönemde, benzer mali ve ticari işlemlerin farklı işletmelerde ve farklı toplumlarda benzer hesapların kullanıldığı muhasebe kayıtları üzerinden gösterimi -özellikle 20.yy. başlarından itibaren- 
yaygınlaşmışır. 18.yy. sonları ve 19.yy. dönemi öngörülen kayıt mant1ğının genel kabul görerek yaygınlaştı̆̆ı, dolayısıyla muhasebe eserlerinin farklı dillere çevrildiği ve seri baskılarının yapıldığ eder. Örneğin Edmond Degrange'ın 1795 yılında yayınlanan La Tenue Des Livres Rendue Facile, ou Nouvelle Methode D'enseignement (Kolay Defter Tutma veya Yeni Öğretim Yöntemi) isimli eseri -çalışma kapsamında eserin 1818 yılındaki 10. baskısına ulaşılmıştır- farklı dillere çevrilmiş ${ }^{4}$ ve 19.yy. boyunca onlarca baskısı yapılmıştır. Nitekim bu eserdeki temel kayıt mantığını esas alan Friedrich Klein'ın "Amerikan Muhasebesi" isimli eseri 1886-1921 yılları arasında 13 baskı yapmış, Serkiz Nihad tarafindan 1916 yılında belirli oranda Türkçe'ye de çevrilmiştir. 20.yy'ın ikinci yarısından itibaren muhasebe kayıt ve raporlarında bir tekdüzen arayışı somut karşılık bulmuştur. Bu dönem aynı zamanda Baudrillard'ın öngördüğü kodları esas alan simülasyon düzeni ile de örtüşmektedir. Zira bu dönemin son çeyreğinden itibaren para da elektronik bir olguya dönüşmeye başlamıştır. Nitekim mali tablolarda sunulan bilgiler somut gerçekliğin yerini almış simülakrlar olarak ekonomik kararları etkileyen, performans ve denetimin ölçütü olan başat faktörlere dönüşmüştür.

Macintosh ve diğerleri (2000) muhasebenin tarihsel gelişim süreci içinde gelir ve sermaye kavramları temelinde simülasyon düzenine nasıl geçildiği değerlendirilmekte, bir simülakr olarak bir varlığın muhasebe kayıtlarındaki değerinin gerçek değerinin yerine hatta önüne geçebildiğini ifade etmektedirler. Modern muhasebe bilgileri gerçek nesne, olay, şeffaf sunum, yönetim sorumluluğu veya bilgi ekonomisi mantı̆̆ına göre yapılan faaliyetlerin birebir karşılığı olarak sunulmaktadır (Macintosh ve diğerleri, 2000, s.13). Macintosh (2002) muhasebe kayıtlarının ve mali tablo kalemlerinin gerçeklikle birebir örtüşen ve -hatta örtüşmese degerçeklik olarak sunulan ve kabul edilen simülakrlara dönüştüğü, ekonomik karar alımlarında muhasebe simülakrlarının esas alındığını değerlendirmektedir. Nitekim bir finansal varlığın muhasebe kayıtlarına piyasa fiyatı üzerinden alındığını, piyasa fiyatının da büyük ölçüde yine muhasebe kayıtlarına dayalı olarak hazırlanan ve sunulan mali raporlar doğrultusunda şekillendiğini döngüsel bir yaklaşımla ele almaktadır. Bu

\footnotetext{
${ }^{4}$ Bu çevirilere örnek olarak Ispanyolca'da Perez (1826) ve italyanca'da Verdinois (1837)'in farklı baskıları yapılmış çevirileri verilebilir. 1837-1894 yılları arasında eserin 8 farkı baskısının Portekizce'ye çevrildiği de bilinmektedir (Carvalho vd., 2003:6).
} 
yaklaşım sunulan muhasebe bilgilerinin simülakr niteliği taşıması halinde de piyasa fiyatını yönlendirebileceğine işaret etmektedir (Macintosh, 2002, s.31).

Gårseth-Nesbakk (2011, s.249), simülasyon ve muhasebe ilişkisini muhasebe bilgilerinin işletmenin örgütsel faaliyetleri ve finansal işlemleri ile örtüşmediği durumlarda gerçeği temsil edemeyeceğini ileri sürerek değerlendirmiştir. Ancak simülasyon bir gerçeküstülük olarak değil gerçekliğin yerine geçmiş yapay gerçeklik olarak tanımlandığında bu görüş desteklenemeyecektir. Zira sadece muhasebe bilgilerinin oluşturduğu simülakrlar işletmelerin bireyler, diğer işletmeler, toplum ve devletle olan ilişkilerinde belirleyici rol oynamaktadır.

Yukarıda genel çerçevesi çizilmeye çalışılan muhasebenin Simülasyon Kuramı ile ilişkisi çalışmanın takip eden bölümlerinde, kişilik ve işletmenin sürekliliği varsayımları ile seçilmiş muhasebe uygulamaları, raporlama ve denetim süreçlerinde simülasyon ve simülakrların değerlendirilmesi şeklinde farklı açılardan kurgulanmıştır.

\subsection{Kişilik ve İşletmenin Sürekliliği Varsayımları Bağlamında Muha- sebe ve Simülasyon Kuramı İlişkisi}

Muhasebe uygulamalarının teorik temellerinden ve temel varsayımlardan olan kişilik ve işletmenin sürekliliği varsayımlarının Baudrillard'ın (2014, s.33) simülasyon için tanımladığı "gerçeğin yerini almış modeller" ifadesini karşılayarak muhasebe ve Simülasyon Kuramı ilişkisinin temel unsurlarından olduğu belirtilebilir.

Muhasebede kişilik varsayımı, işletmenin sahip veya ortaklarından, yöneticileri, çalışanları veya diğer ilgililerden ayrı bir kişiliğe sahip olduğu ve muhasebe işlemlerinin sadece bu kişilik adına yürütülmesi gerektiği esasına dayanmaktadır (Akdoğan ve Sevilengül, 2007, s.6). Modern muhasebe uygulamalarının temel varsayımlarından olan sürekli ömre sahip bir ticari kişilik bir tür simülasyon kahramanıdır (kişilik simülakrı). Buna göre gerçek kişiliklerden türetilmiş ticari kişilik, hak ve yükümlülük ilişkisi kurabilmesine, sorumluluk üstlenebilmesine rağmen işletmenin sahip ve ortaklarının yaşam süreleriyle sınırlı olmayan -aksi belirtilmedikçe- sonsuz bir ömre sahip olması sebebiyle gerçek üstü bir simulatif kişiliktir. Borçlanma/alacaklanma şeklindeki temel çalışma 
prensibi doğrultusunda teorik olarak hak ve yükümlülük üstlenen muhasebe hesaplarının kişiliği de bu yönde değerlendirilebilir. Nitekim Bunau-Varilla (1924) muhasebenin, işletmenin bir temsilcisi gibi hareket eden simgesel kişilik sahibi bir dizi hesap vasıtasıyla çalıştığını ifade etmiştir. Faure (1927) ise bu hesapların bir kişi gibi davrandıklarını zira hak ve yükümlülük ilişkisine girdiklerini belirtmiştir (Catalo ve Girlando, 2012).

Muhasebenin kişilik varsayımının dayanağı olan Kişilik Teorisi, modern muhasebenin işletme ve birimlerinin faaliyetlerini ele alırken esas aldığ kişilik, işletmenin hesap ve raporlarının yegâne sorumlusu olup, bu hesap ve raporlar ortak, çalışan veya ilgili herhangi bir kişi veya gruba ait olarak değerlendirilmemektedir. Bu teoriye göre hasılat ve giderler, kar ve zararlar sermayedarların varlıklarının değil işletmenin varlıklarının değişimi sonucu açığa çıkmaktadır. (İktisadi Devlet Teşekkülleri Yeniden Düzenleme Komisyonu/IDTYDK), 1968, s.17-18). Muhasebe, eylemlerinde ticari kişiliğe karşı sorumlu olup işletme sahipleri veya personelleriyle kurduğu ilişkiyi "Ortaklara Borçlar/Ortaklardan Alacaklar" ve "Personele Borçlar/Personelden Alacaklar" şeklindeki hesaplarda görüldüğü üzere üçüncü kişilerle gerçekleştirir biçimde kaydetmektedir.

Kişilik varsayımının bir izdüşümü olan ve muhasebenin temel kayıt mantığını oluşturan çift yanlı kayıt yöntemine dayalı olarak geliştirilen bilanço temel denkliğinde her varlığın bir kaynak (borç veya özkaynak) veya her kaynağın bir varlık şeklindeki eşit tutarlı karşılıkları bulunmaktadır. Burada iktisadi bir değerin sahiplik veya mahiyet değiştirmesi söz konusu olduğundan hem varlık hem de kaynak bir diğerinin özdeş yansısı olarak kaydedilmektedir. Bu durumda ticari kişiliğin idaresindeki işletme varlıkları, sermaye payı veya borç verilen tutarların yani gerçek varlıkların işletmedeki yansımaları olarak bir tür simülakra dönüşmektedir.

İşletme sahibi ve/veya ortaklarından bağımsız, gerçek bir kişi gibi hak ve yükümlülük ilişkisi kuran, kendi adına ve sorumluluğunda muhasebe hesapları, defter ve belgeleri açan/kullanan ve adına mali raporlar düzenlenen ticari kişilik, gerçekliğin yerini almış bir tür yapay gerçeklik görünümü yani bir muhasebe simülakrı olarak değerlendirilebilecektir. 
İşletmenin ticari kişiliğinin ömrünün aksi belirtilmedikçe, işletme sahip ve ortaklarının ömürlerinden bağımsız, yani teorik olarak sınırsız kabul edilmesi işletmenin sürekliliği varsayımı olarak ifade edilmektedir (Akdoğan ve Sevilengül, 2007, s.6). İşletmenin ömrünün ne zaman sonlanacağının öngörülmemiş olması, dolayısıyla ticari kişiliğe sınırsız bir yaşam ömrü tanımlanması gerçek üstü bir durum olmakla birlikte muhasebenin esas aldığ kaydetme, tahakkuk esaslı işlemler, amortisman ayırma, karşılık ayırma, tahvil çıkarma, yedek akçe ayırma gibi pek çok muhasebe uygulamasının da dayanağını oluşturmaktadır. İşletmenin sürekliliği, işletme faaliyetlerinden etkilenen tüm gerçek ve tüzel kişilerin ekonomik kararlarını etkileyebilecek bir nitelik taşımaktadır. Nitekim işletmeden, sürekliliğini tehlikeye düşürebilecek olası durumlara karşı mali tablolarında gerekli açıklamaları yapması beklenmektedir. Bu doğrultuda, Türkiye Muhasebe Standardı/TMS 1 "Finansal Tabloların Sunuluşu" standardının 25. ve 26. paragraflarında ve Bağımsız Denetim Standardı/BDS 570 "İşletmenin Sürekliliği" standardında, işletmenin sürekliliğini devam ettirme kabiliyetine ilişkin ciddi belirsizlik ve risklerin belirlenmesi ve mali tablo dipnotlarında açılanmasına ilişkin hükümler bulunmaktadır (Kamu Gözetimi Muhasebe ve Denetim Standartları Kurumu /KGK, 2017; KGK, 2018a).

İşletmenin sürekliliği varsayımı, işletme sahip ve ortakları, çalışanları ve üçüncü kişi ve kurumların işletme ile olan gerçek nitelikli ilişkilerini belirleyen gerçeküstü bir varsayım olarak açı̆̆a çıkmaktadır. İşletmenin iktisadi varlığını devam ettireceği esas alınarak diğer kişi ve kurumların işletme ile uzun vadeli hak ve yükümlülük ilişkileri kurmaları, yapay bir gerçeklik olan işletmenin sürekliliği varsayımının muhasebede temel gerçeklik olarak kabul edilmesinin bir sonucudur. Bu doğrultuda işletmenin sürekliliği varsayımı ve bu varsayıma dayalı muhasebe uygulamaları, sınırlı bir yaşam süresinin sınırsız veya öngörülemeyen bir sınırlilıkta olmasının gerçeklik olarak kabul edilmesi yönüyle simülakr (süreklilik simülakrı) olarak tanımlanabilecektir. 


\subsection{Muhasebe Uygulamaları Açısından Simülakr Örnekleri}

Baudrillard (2014, s.16) simülasyonun "günümüzde hakikat ilkesinin yerini aldığını" belirtmektedir. Simülasyonun modern dünyanın gerçekliği haline dönüşmesi, parasal nitelikli mali eylemlerin kayıt, sınıflandırma, analiz ve raporlama çerçevesini belirleyen muhasebede de temellenebilecektir. Nitekim bir takım muhasebe faaliyeti, henüz somut olarak gerçekleşmemekle birlikte mali tablolarda yerini alan muhasebe gerçeklikleri olarak sunulmaktadır. İşletmenin varlık ve kaynak yapısını etkileyen bu uygulamalar simülasyon evreninin bir gerçekliği yani bir tür simülakr olarak değerlendirilebilecek niteliktedir. Baudrillard (2014, s.19) simülasyonun "...sahte bir yeniden canlandırma biçimi olmayıp, yeniden canlandırma düzeninin tamamın bir simülakra dönüştürmekte..." olduğunu ifade etmiştir. Nitekim aşağıda örnekleri değerlendirilen muhasebe simülakrları ile somut muhasebe gerçeklikleri arasında ekonomik etkileri ve sonuçları açısından belirgin farklar yer almamaktadır. Muhasebe simülakrları da işletmelerin dönem sonu kar veya zararlarını, ödenecek temettüleri, vergi ödemelerini, ilgili kişi veya kurumların ekonomik kararlarını benzer biçimde etkilemektedir.

Henüz tahsil veya tediye edilmemiş senetler dönem sonunda tasarruf değeri ile değerlenerek reeskont işlemine tabi tutulmakta, reeskont tutarı bilançoda ilgili düzenleyici hesaba kaydedilmekte, nakit girişi ve çıkışı üzerinde doğrudan etkisi olmayan 647 Reeskont Faiz Gelirleri veya 657 Reeskont Faiz Giderleri hesapları vasıtasıyla da gelir tablosunda raporlanmaktadır. Reeskont ayrılacak senedin yabancı para birimi cinsinden düzenlenmesi halinde kur farkları da dikkate alınmak durumundadır.

Senetli veya senetsiz alacakların kendileri de simülakr (alacak simülak$r$ r) olarak değerlendirilebilir. Zira alacak tutarı işletme varlıkları arasında gösterilmekle birlikte henüz vadesi dolmadığından tahsil edilmemiş ancak gelecekte tahsil edileceği varsayımıyla bilançoda ayrı hesap grupları altında (12./22. Ticari Alacaklar, 13./23. Diğer Alacaklar) raporlanmıştır. Ticari veya diğer alacakların vade sonunda tahsil edilememe olasılığı dikkate alındığında, bu varlıkların kısmen veya tamamen gerçeklik yanılsamaları da barındırdığı belirtilebilir. Bu yönüyle bir tür simülakr olarak değerlendirilebilecek olan senetli alacaklara reeskont ayrılması işlemi ise simülakrn simülakr görünümü arz etmektedir. Zira işletmede 
nakden var olmayan ancak taahhüden kaydedilen önemli bir varlık kaleminin (senet simülakrı) dönem sonunda tahsil edileceği varsayımı ile hesaplanacak tasarruf değeri dolayısıyla reeskont tutarının da kayıt altına alınması ve raporlanması (reeskont simülakrı) bu yargıyı destekler nitelikte görünmektedir. Benzer bir çıkarım senetli ve senetsiz borçlar ile borç senetleri reeskontu işlemleri için de değerlendirilebilir.

İşletmelerin kasa veya banka hesaplarında mevcut yabancı paralar değerleme tarihinde TL'ye dönüştürülmemiş olmakla birlikte kur artış veya azalışları 646 Kambiyo Karları/656 Kambiyo Zararları hesaplarında izlenmektedir. Bu doğrultuda yabancı paralı işlemlerin dönem sonu değerlemeleri için de bir tür simülakrdan (kambiyo simülakrı) söz edilebilecektir.

Karşılık ayırma işlemleri de muhasebede simülakr (karşılık simülakrı) örneği olarak sunulabilir. İşlem tarihi itibariyle kesinleşmemiş olmakla birlikte tahsili şüpheli hale gelmiş alacaklara karşılık ayrılmakta, bilançoda ilgili düzenleyici hesabın yanında 654 Karşılık Giderleri Hesabı'na kaydedilerek yine gelir tablosunda raporlanmaktadır. Menkul kıymet değer düşüklüğü ve stok değer düşüklüğü karşılıkları, diğer dönen varlıklar karşılığı, iştirakler veya bağlı ortaklıklar sermaye payları değer düşüklüğü karşılıkları da simülakr olarak değerlendirilebilecek diğer karşıllk ayırma örneklerindendir.

Muhasebede işletmenin sürekliliği varsayımı doğrultusunda aksi belirtilmedikçe sınırsız veya öngörülebilir bir sınırlılıkta olmadığı kabul edilen işletme ömrü, dönemsellik kavramı uyarınca belirli faaliyet bölümlerine ayrılarak her dönemin faaliyet sonucu diğer dönemlerden bağımsız olarak tespit edilmektedir. Nitekim gelir ve giderlerin tahakkuk esasina göre tahsil veya tediye edilmeleri şartı aranmaksızın kesinleştikleri dönemde ilgili hesaplara alınması gerekliliği de bu kavramla ilişkilidir. Mevcut dönemde ortaya çıkmış ancak ilgili kişi veya kurumlardan tahsil edilmesi veya adlarına borç kaydı yapılması gelecek hesap dönemine veya dönemlerine kalmış olan gelirler, ilgili gelir hesabına aktarılmakla birlikte 181/281 Gelir Tahakkukları Hesabı'na kaydedilmektedir. Mevcut hesap döneminde oluşan ancak ödenmesi gelecek dönem veya dönemlerde yapılacak olan giderler de ilgili gider hesabının karşılığında 381/481 Gider Tahakkukları Hesabı'nda izlenmektedir (İstanbul Serbest Muhasebeci Mali Müşavirler Odasi/ISMMMO, 2006, s.15,128,163). Söz 
konusu tahakkuk işlemlerinde belgeye dayalı olmakla birlikte tahsil veya tediye gerçekleşmemiş, ancak gelir veya gider muhasebe kayıtlarına alınarak faaliyet sonuçlarının bu durumdan etkilenmesi sağlanmıştır. İşletmede ilgili dönemde somut olarak nakdi bir varlık veya kaynak değişimine sebep olmayan ancak bu artışın hesapsal olarak izlenebildiği tahakkuk işlemleri muhasebenin yapay gerçekliklerine verilebilecek önemli örneklerdendir. Tahsil veya tediye ile birlikte yapay gerçeklik hali gelecek hesap dönemi/dönemlerinde ortadan kalkabilecek olmakla birlikte söz konusu işlemler bu döneme kadar simülakr (tahakkuk simülakrı) olarak varlığını sürdürecektir.

Amortisman işlemleri de muhasebede simülakr kullanımına örnek olarak verilebilir. Maddi duran varlıkların kullanım süreleri içinde aşınma, yıpranma vb. nedenlerle uğradıkları değer kayıplarının gider yazılması işlemi olan amortisman işlemlerinde hesaplama, duran varlıkların faydalı ömrünü odak almaktadır. Ancak Maliye Bakanlığı'nca yayınlanan amortismana tabi iktisadi kıymetlere ilişkin genel tebliğler doğrultusunda belirlenen ortak faydalı ömürler ve bu doğrultuda hesaplanan amortisman paylarının varlığın gerçek aşınma ve yıpranma tutarı ile örtüşmemesi söz konusu olabilmektedir. Amortisman tutarı net nakit çıkışına sebep olmamakla birlikte bir gider kalemi olarak işletmenin dönem karı veya zararını da etkilemektedir. Maddi duran varlıktaki aşınma ve yıpranma dolayısıyla oluşan değer kaybının mali tablolara yansitılması gerekliliği, nakit çıkışına sebep olmasa da amortismanın somut bir gerçeklik olarak nitelendirilmesini sağlamaktadır. Hesaplanan amortisman tutarının ilgili duran varlıkta söz konusu dönemde oluşan kullanım kaynaklı değer azalışını tam olarak karşılayamaması durumunda, raporlanan amortisman ile kullanım kaynaklı gerçek değer azalışı arasında fark oluşacağından amortisman bir tür muhasebe simülakrına (amortisman simülakrı) dönüşmüş olacaktır. Öyle ki her yıl eşit taksitlerle amostisman ayırma (normal yöntem) veya faydalı ömrün ilk yıllarında daha fazla son yıla kadar diğer yıllarda giderek daha az ve son yıl bir önceki yılın kalan değerinin tamamının amorti edilmesi şeklindeki amortisman ayırma (azalan bakiyeler/kalanlar) yöntemlerinin duran varlığın kullanıma bağlı gerçek değer azalışını tam olarak yansıtmadı̆̆ı görülmektedir. Bununla birlikte TMS 16 "Maddi Duran Varliklar" standardınca faydalı ömrün işletmenin ilgili varlıktan beklediği faydaya göre tahmin 
edilmesi ve işletmenin takdirine bırakılması, faydalı ömrün ve kalıntı değerin her hesap dönemi sonunda gözden geçirilmesi ve gerekli hallerde tahmin değissikliklerinin yapılması, doğrusal (normal) ve azalan bakiyeler yöntemlerine ek olarak varlığın beklenen kullanım veya üretim miktarına göre amortisman hesaplamasına imkan veren üretim miktarı yöntemi ${ }^{5}$ nin varlığı, varlığın gerçeğe uygun değerinin güvenilir bir biçimde ölçülebilir olması durumunda yeniden değerlenmiş tutar üzerinden gösterilmesi ve amortisman hesaplamalarının buna göre düzenlenmesi $^{6}$ gibi işlemler hesaplanan ve raporlanan amortisman tutarı ile kullanıma dayalı gerçek değer azalışı arasındaki farkı azaltmakta veya ortadan kaldirabilmektedir (KGK, 2014, s.9-13). Farkın tamamen ortadan kalkması durumunda amortisman simülakrından söz edilemeyecektir.

Baudrillard (2014, s.18)'a göre "Gerçeğin yerine geçen simülakr, artık gerçeğin değil sadece kendi kendinin yerine geçmekte olan bir şeydir." Bu yarg1 ile muhasebenin kayıt altına aldığı ve raporladığı menkul kıymetler arasında ilişki kurulabilir. Örneğin işletmede kısa vadeli yatırım amacıyla bulundurulan hisse senetleri fiyat artış/azalışlarından kısa vadeli kazanç sağlamak amaciyla Menkul Kiymetler Hesap Grubu altında 110 Hisse Senetleri hesabında kayda alınarak raporlanmaktadır. Burada hisse senedi şirket sermayesini temsil eden bir kıymetli evrak olmaktan ziyade kendisi bir metaya dönüşmüş, şirket dışı etkenlere ve spekülasyonlara oldukça açık bir varlık konumundadır ${ }^{7}$. Bu yönüyle hisse senedi bir simülakr (hisse senedi simülakrı) olarak değerlendirilebilir. Benzer bir yaklaşım menkul kıymetler hesap grubunda izlenen kamu/özel kesim tahvilleri, hazine/finansman bonoları, yatırım fonu katılma belgesi, kar-zarar ortaklığı belgesi ve gelir ortaklığı senedi gibi varlıklar için de geçerlidir. $\mathrm{Bu}$ varlıklar faiz geliri veya kar payı sağlamanın yanında farklı fiyatlardan vade süresince sıklıkla el değiştiren, ödeme, tahsilat veya teminat

\footnotetext{
5 Üretim miktarı yöntemi, TMS 16'da tanımlanan alternatif bir amortisman yöntemi olup maddi duran varlığın yeniden değerlenmesi üzerinde doğrudan bir katkısı bulunmamaktadır. Bununla birlikte doğrusal (normal) ve azalan bakiyeler yöntemlerine göre varlığın kullanımına mukabil oluşacak değer azalışını ve dolayısıyla amortisman tutarını kısmen daha doğru yansıtması söz konusudur.

${ }^{6}$ Gerçeğe uygun değerle değerleme sonucu elde edilen tutarın varlığın gerçek değerini ne ölçüde yansıtıyor olduğu tartışılabilir. Yeniden değerlenmiş tutar ile varlığın gerçek değeri arasında farklılık oluşması durumunda amortisman simülakrından da söz edilebilecektir.

${ }^{7}$ Hisse senetlerinin simülakr özelliği için dikkat çekici bir örnek olarak Çin'in en büyük petrol ve doğalgaz üreticisi PetroChina şirketi verilebilir. Şirketin 2007 yılında Şangay Borsası́nda piyasa değeri 1 trilyon doları aşmış ancak 2008 sonunda 3/4 oranında değer kaybederek 260 milyar dolara kadar inmiştir.
} 
belgesi olabilen, ifade ettiği temel gerçeklikten uzaklaşarak "kendi kendinin yerine geçmekte olan" bir simülakra (menkul kıymet simülakrları) dönüşen hesapsal varlıklara evrilmişlerdir.

Muhasebenin konusu olan türev ürünler de simülakr olarak nitelendirilebilecek varlıklardandır. Bu ürünler, değerleri emtia, hisse senedi, altın, faiz, döviz kuru gibi finansal varlıkların değerine bağlı olarak değişen, muhasebeleştirilen ve mali tablolarda raporlanan finansal araçlardır. Finansal riskten korunma/hedging veya belirsizlikle mücadelede kullanıldıkları gibi volatiliteleri baz alınarak spekülasyon amacıyla da bulundurulabilmektedir. Hatta organize borsalarda işlem gören türev ürünler genellikle spekülasyon amaçlı kullanılmaktadır (Kayahan, 2009, s.24). Türev ürünler finansal simülakrlar (türev simülakr) olarak değerlendirilebilirler. Söz konusu ürünler bir varlığa dayalı finansal sözleşme olmanın ötesinde kendileri varlığa dönüşerek alınıp satılan, organize piyasalarda işlem gören yatırım araçlarıdır. Nitekim türev ürünlerin dayandığı hisse senedi, faiz, döviz kuru gibi unsurlar da gerçekte bir varlığı/ekonomik bir değeri esas almakla birlikte finansal piyasalarda kendileri finansal varlıklara dönüşmüş olmaları yönüyle bir tür simülakrdır. Bu açıdan değerlendirildiğinde örneğin bir döviz veya faiz swapı, döviz veya faiz simülakrından türetilmiş yeni bir simülakr (simülakrın simülakrı) olarak görülebilir.

Bougen ve Young (2012), finansal araçların gerçeğe uygun değerle ölçüm ve değerlemelerinde simülakr ve simülasyon ilişkisini incelemişlerdir. Çalışmada finansal araçların gerçeğe uygun değerleriyle ölçüm ve değerleme işlemlerinin bir simülasyon oluşturduğu değerlendirilmiştir. Nitekim işletmenin özkaynağa dayalı bir finansal aracı ölçüm tarihinde piyasa katılımcısına devrediyor olduğunun varsayılması esasıyla belirlenen gerçeğe uygun değer, ölçüm tarihinde gerçekleşebilecek olağan bir işlemdeki fiyatın tahmin edilmesi şeklinde açığa çıkmaktadır. Burada gerçekleşmemiş bir devir işleminin varsayılması ve gözlemlenebilir ve gözlemlenemeyen girdilerden yola çıkılarak tahmin edilen fiyatın esas alınması bir tür simülasyon açığa çıkarmaktadır. Nitekim kendi özkaynağına dayalı özdeş veya benzer bir finansal aracın veya borcun devrine yönelik bir kotasyon fiyatı bulunmadığında "işletme bu finansal aracın veya borcun gerçeğe uygun değerini, ölçüm tarihinde özdeş kalemi varlık olarak elinde tutan bir piyasa katılımcısının bakış açısıyla" ölçmektedir. Gözlemle- 
nebilir girdilerin bulunmaması halinde ise farklı değerleme yöntemleri kullanabilmektedir. Bu yöntemlere örnek olarak Gelir Yaklaşımı ve Piyasa Yaklaşımı sunulmaktadır. Gelir Yaklaşımı'nda "bir piyasa katılımcısının özkaynağa dayal finansal aracı veya borcu varlik olarak elinde tutarak elde etmeyi beklediği gelecekteki nakit akışların dikkate alan bugünkü değer yöntemi" kullanılırken Piyasa Yaklaşımı'nda "diğer taraflarca varlık olarak elde tutulan benzer özkaynağa dayal finansal araçların veya borçlarm kotasyon fiyatla$r{ }^{\prime \prime}$ esas alınmaktadır. Özdeş veya benzer bir finansal aracın veya borcun devrine ilişkin bir kotasyon fiyatı bulunmadığında ve başkası tarafından varlık olarak elde tutulan özdeş bir kalem bulunmadığında ise gerçeğe uygun değer "özkaynak üzerindeki hakkı ihraç eden veya borçlu konumda olan bir piyasa katılımcısının bakış açısıyla" bir değerleme yöntemi kullanılarak ölçülmektedir (KGK, 2018-b, s.6-8). Finansal araçların gerçeğe uygun değerle ölçümü ve değerlemesinde gerçek tutar ile ölçülen ve değerlenen tutar arasında fark oluşabilmesi ve raporlanan tutarın somut gerçeklik yerine bir muhasebe gerçekliğine dönüşebilmesi sebebiyle bir tür simülakr (finansal araç simülakrı) oluşumuna sebep olacağı belirtilebilir. Nitekim finansal araçların gerçeğe uygun değerle değerlemesi işlemlerinde yoruma açıklık ve uygulayıcıların yargısına bırakılan faktörlerin belirsizliği ve bu varlıkların volatilitesini artırdığı, bu durumun ise finansal krizin tetikleyicilerinden olduğu ifade edilmektedir (Şımga-Mugan ve Hacıhasanoğlu, 2010). 2008 finansal krizinde varlığa dayalı menkul kıymetlerin rolü de bu bağlamda değerlendirilebilir. Kriz öncesi ipotek karşıllı̆̆1 gayrimenkul kredisi veren finans kurumları, bu kredileri satarak veya varlığa dayalı menkul kıymet çıkararak mevcut kredileri fonlamışlardır. İpoteğe dayalı bu menkul kıymetlerin riskli görünenleri yüksek getiri vaadiyle satılmıştır. Varlığa dayalı menkul kıymet fiyatlarında düşüş, satılamayan gayrimenkul birikimi, kredi borçlularının geri ödeme güçlüğü gibi unsurların etkisinin 2008 finansal krizinin temel etkenleri olduğu belirtilmiştir (Akgüç, 2009, s.7). İpotekli varlıklara dayalı menkul kıymetlerin değerlemesinde gerçeğe uygun değerin kullanılmasının finansal krizin derinleşmesinde etkili olduğu ifade edilmiştir (Topbaş, 2009, 61).

“Simülasyon ilkesinin belirlediği günümüz dünyasında gerçek, modelin varlığını kanıtlamaktan başka bir işe yaramamaktadır. Paradoksal bir şekilde gerçeği hakiki bir ütopyaya dönüştürdük..." (Baudrillard, 2014, s.160). Bu ifadeler 
yakın geleceğin finans dünyasını şekillendirecek olan, ekonomik bir metaya dayanmayan, fiziki bir varlığı olmayan dolayısıyla bir tür simülasyon evreninde geliştirilen kripto para birimlerinin varlığ1 ve bu para birimlerinin muhasebeleştirilmesi ile ilişkilendirilebilir. Web tabanlı, şifrelemeye dayalı denkler arası ödeme sistemleri olan kripto paralar dijital mübadele birimleri olup gerçek mal ve hizmetlerin ödeme aracı olarak sunulan bilgisayar dosyalarıdır. Devlet destekli para birimleri veya bilgisayar oyunlarında kullanılan sanal paraların aksine hiç kimse tarafından piyasa sürülmemekte olan kripto para birimleri kullanıcılar tarafından çıkarılarak varlık kazanmaktadır. Yazılımların kendiliğinden ürettiği matematiksel problemlerin kullanıcının bilgisayarı tarafından çözülmesi durumunda kripto para yaratılmış olmaktadır. Kripto para internet üzerinden mübadele yoluyla devlet destekli paralara veya mal ve hizmetlere dönüşebilmektedir (Marian, 2013, s.41-42). Kripto paralar, Baudrillard (2014, s.164)'ın kurguladığı, ürettikleri ürünlerin günlük hayatta bir karşılığı olmayan ancak üretimi sonlandırmaları halinde sürecin içindeki insanları ekonomik kayba uğratacak "hayalet fabrikalar" da üretilmiş gibi görünmektedir. Somut bir varlığı olmayan, bir varlığa da dayanmayan elektronik kodların oluşturduğu, ancak gerçek mal veya hizmetlerin mübadelesinde bir araca dönüşebilmiş olan kripto paralar, Baudrillard'ın simülakr düzeninin son aşaması olan kodun belirlediği evrenin güncel bir unsuru olarak görülebilir. Kripto para birimleri ödeme, tahsilat ve yatırım aracı olarak da kullanılmaya başlanılan parasal bir değer olarak muhasebenin konusu kapsamına girmekte, kripto paralar kayıt ve raporlama süreçlerine dahil edilmektedir. Bu anlamda kripto paralar bir tür muhasebe simülakrı (kripto simülakr) olarak değerlendirilebilir.

\subsection{Sürdürülebilirlik ve Kurumsal Sosyal Sorumluluk Raporlamaları, Muhasebe Denetimi ve Denetim Skandalları ile Simülakr İlişkisi}

Boiral (2013), GRI bazlı sürdürülebilirlik raporlarının gerçek sürdürülebilir gelişme sorunlarını örterek işletmelerin durumlarıyla ilgili ideal bir görünüm sunan bir tür simülakr olduğunu değerlendirmektedir. Benzer bir biçimde Corazza, Scagnelli \&Mio (2017), sürdürülebilirlik raporlarında sunulan "ortak değer yaratma/creating shared value" açılamalarını bir 
tür simülakr olarak ele almışlardır. Çalışmada işletmelerin ortak değer yaratma faaliyetlerine ilişkin açıklamaların kurumsal sosyal sorumluluk veya filantropi/hayırseverlik amaçlı olmaktan çok sürdürülebilirlikle ilişkili olduğu, bunun da paydaşların baskısını azaltmak için bir araç olarak kullanıldığı değerlendirilmiştir. Ortak değer yaratma açıklamaları ve grafik sunumlarının gerçekliğinin tartışmalı olduğu ancak gerçeklik olarak sunulduğu, bu vasitayla muhasebe verilerinin de kullanıldığı simülakrlar olarak paydaşlara sunulduğunu ifade etmişlerdir. Sürdürülebilirlik muhasebesi, raporlaması ve hesap verebilirlik vurgusu gerçekliğin simülakrı olarak değerlendirilmiş, çıkar gruplarına sunulan açıklamalar Platon'un Mağara Alegorisi'ndeki insanların gerçek dünyayı sadece nesnelerin yansımalarından yola çıarak değerlendirmelerinde oluşan duruma benzetilmiştir (Corazza ve diğerleri, 2017, s.431).

Kurumsal sosyal sorumluluk (KSS) uygulamaları, sermayenin emeği ikna etme sürecinde önemli bir etkisi olduğu (Ayhan, 2009, s.180), çıkar gruplarının işletme üzerindeki baskısını azaltarak piyasanın yeni Görünmez $E l$ 'i ve devletin işletme üzerindeki kontrolünü etkisizleştirebilen Laissez -Faire (Bırakınız yapsınlar) amaçlı uygulamalar için bir araç olarak kullanıldığı (Fleming ve Jones, 2013, s.31) gerekçeleriyle eleştirilmektedir. Tarihin en büyük çevre felaketlerinden biri olarak kayıtlara geçen British Petroleum/BP'nin Deepwater Horizon petrol platformunda 2010 yılının Nisan ayında yaşanan patlama ve tüm Meksika Körfezi'ni etkileyen 4 milyon varilin üzerindeki ham petrol sızıntısından (Hoffman ve Jennings, 2011) önce şirketin yayınladığ 1 çevresel ve sosyal raporlardaki idealize açıklamalar ve yaklaşımlar (BP Sustainability Review, 2009), bu tür raporların işletme algısının ve dolayısıyla çıkar gruplarının ekonomik karar alımlarının simülakrlarla nasıl değiştirilebileceğine verilebilecek örneklerdendir8. İşletmelerin -somut gerçeklikle örtüşmese bile- çıkar gruplarına gerçeklik olarak sundukları ve ilgili grupların işletmeye yönelik alg1 ve eylemlerini etkileyen/değiştiren bu tür raporlar da simülakr (sürdürülebilirlik simülakrı, KSS simülakrı) olarak nitelendirilebilecektir.

\footnotetext{
${ }^{8}$ Benzer bir durum bazı dünya devi otomobil üreticisi firmaların (Volkswagen/2015, Mercedes/2018) emisyon skandallarında da söz konudur. Üretilen araçların egzoz emisyon değerlerinin manipüle edilmesi yoluyla gerçekleştirilen satışlar dolayısıyla oluşan manipülatif mali raporlama ile çıkar gruplarının şirketlerle ilgili ekonomik kararlarının yanlış yönlendirilmiş olduğu belirtilebilir.
} 
Macintosh ve Shearer (2000) çalışmalarında muhasebe, denetim ve simülakr ilişkisini ele almışlardır. Finansal gerçeklik olarak sunulan ancak somut gerçeklikle örtüşemese dahi onun yerini almış bulunan muhasebe kayıtları ve mali tablolar simülakr, denetçinin muhasebe kayıtları ve mali tabloları esas alan denetim raporu ise simülakrın simülakrı olarak tanımlanmıştır. Nitekim olumlu denetçi raporlarının oluşturduğu yapay gerçekliğin finansal skandallar için bir tür kılıf olduğu Enron, Global Crossing, WorldCom gibi skandal örnekleriyle birlikte görülmüştür.

Bilanço süslemeleri, kazanç yönetimi gibi muhasebe manipülasyonlar1 ve muhasebe hilelerinin oluşturduğu gerçek görünümlü ancak somut gerçeklikle örtüşmeyen görüntüler ve bunları destekleyen muhasebe kayıtları, muhasebe eliyle yaratılan bir simülasyon evreninin kendi içinde yaratılan simülakrlarıdır. Bu simülasyonun en bilinen örneklerinden biri Enron Skandalı'dır. Amerika Birleşik Devletleri'nin en büyük şirketlerinden olan Enron 16 yıl içinde aktif büyüklüğünü 10 kat artırmış ve 63,4 milyar dolar toplam aktif büyüklüğüne ulaşmış ancak beklenmedik bir hızla iflas etmiştir. Başlangıçta gerçekçi rakamlara dayalı olan bu büyüme rekabet avantajını korumak içi kısa bir süre sonra yerini spekülatif bir büyümeye bırakmıştır. Hisse senedi fiyatlarının şirketin gerçek dışı karlılık ve büyüme rakamlarıyla doğru orantılı olarak arttığı bir balon oluşturulmuştur. Dünyanın en büyük mali müşavirlik ve denetim şirketlerinden biri olarak görülen Arthur Andersen bu spekülatif büyümede kilit rol oynamıştır. Şirket gelirleri ve dolayısıyla dönem karı şişirilirken mali yükümlülüklerin gizlenmesine göz yumulmuştur. Enron'un muhasebe birimi daha önceden Enron'un denetiminde görevlendirilmiş olan Arthur Andersen çalışanlarından oluşturulmuş ve çalışanlar şirketle tam bir işbirliğine zorlanmış aksi durumda ivedilikle personel değişikliği yapılmıştır. Somut yatırımlar olarak sunulan ancak aslında türev finansal araçlara dayanan işlemler, yerine getirilmeyen vergi yükümlülükleri, nakit karşılığı olmayan sermaye artışları, özel amaçlı varlıklardan elde edilen uygunsuz kişisel kazançlar gibi pek çok faaliyet muhasebe ve denetim süreçlerinde görmezden gelinmiştir (Memiş, 2012, s.152-154). Nitekim Mattessich (2003, s.466-469), Enron Skandalı'nda, banka iflaslarında veya finansal skandallarda muhasebe bilgilerinin rolüne dikkat 
çekmiş, simülakr olarak muhasebe bilgilerinin oynadığ 1 yapay gerçeklik rollerini değerlendirmiştir.

Enron, Global Crossing, WorldCom gibi şirketlerde yaşanan denetim skandalları muhasebe verileri kullanılarak oluşturulan simülasyonun doğal bir sonucu olarak görülebilir. Zira sosyal paydaşların işletme ile ilgili ekonomik kararlarında esas almak durumunda oldukları mali tablo bilgileri, gerçekliğin yerine geçmiş bir simülakra (denetim simülakrı) dönüşmüştür.

\section{Sonuç}

Muhasebe bilgileri, iktisadi ve ticari gerekliliklerin bir sonucu olarak açığa çıkmakta, her bir kayıt belgesel kanıtlara dayandırılmaktadır. Bu çalışmanın amacı bir kısım muhasebe uygulamasının ve bu uygulamalar neticesinde açığa çıkan muhasebe bilgilerinin gerçek dışılığını iddia etmek veya gerekliliğini tartışmak değildir. Aksine modern toplumun yapısını ve toplumsal ilişkileri açıklamak için geliştirilmiş en önemli kuramlardan biri olarak görülen Baudrillard'ın Simülasyon Kuramı'nın muhasebedeki olası karşılıklarını değerlendirmek, muhasebenin sosyolojik bağlantısına bir katkı sunmaya çalışmaktır.

Muhasebe, modern toplumun finansal veri ve bilgi kaynağını teşkil etmekte, ekonomik yaşantısının ve kararlarının merkezinde yer almaktadır. Bu doğrultuda muhasebe, modern toplumun değişim süreçlerine hızla tepki vererek yeni enstrümanlar geliştirebilmektedir. Bu durum toplumsal dönüşümün bir tür yeniden izahı ve eleştirisi olarak değerlendirilecek Simülasyon Kuramı'nın muhasebe ile olası bağlantılarına işaret etmektedir. Bu doğrultuda çalışmada muhasebenin temel varsayımları ve uygulamaları ile Baudrillard'ın Simülasyon Kuramı bağlamında simülasyon ve simülakr ilişkisi irdelenmiştir. Bu ilişki kişilik ve işletmenin sürekliliği varsayımları, senetli ve senetsiz alacaklar, reeskont işlemleri, yabancı paralı işlemlerin dönem sonu değerlemeleri, karşılık ayırma işlemleri, gelir ve gider tahakkukları, amortisman işlemleri, menkul kıymetler, türev finansal ürünler, finansal araçların gerçeğe uygun değerle ölçümü, kripto para birimleri, sürdürülebilirlik ve kurumsal sosyal sorumluluk raporları ile denetim skandalları örnekleri üzerinden ele alınmıştır. 
Muhasebe ile simülasyon ve simülakr ilişkisi farklı örnekler üzerinden de çeşitlendirilebilir. Nitekim envanter işlemlerinin simülasyon ile somut gerçekliği örtüştürme işlevini de yürüttüğü belirtilebilir. Örneğin Kasa Hesabı, gerçek kişi olan vezne görevlisinin/kasa sorumlusunun faaliyetleri sonucu şekillenmektedir. Kasa Hesabı'nın kişiliği gerçek kasa sorumlusunun kişiliği sebebiyle gerçekle örtüşen veya gerçek dışı bir biçimde davranabilmektedir. Gerçek dişı davranmış kasa sorumlusu, Kasa Hesabı'nın dolayısıyla bilançonun gerçek dışı hazırlanmasına neden olacaktır. Mali tablo kullanıcıları açısından ise sunulan bu bilgi bir muhasebe gerçekliği yani bir tür simülakr olarak kabul edilecek ve karar alımlarında etkin olacaktır. Ancak envanter sayesinde yapılan hatalar tespit edilerek kasa noksanı veya fazlalıkları açığa çıkarıldığında mevcut nakdi durum ile hesapsal bilgi yani gerçekle simülakr örtüştürülmüş olacaktır.

"Hesap ve akılcı üretime evrensel bir amaç kazandırma simülasyonu; simgesel değiş tokuşun amaç ve belirleyicilikten bihaber olduğu yerde bir belirleyicilik simülasyonudur..." (Baudrillard, 2013, s.138). Her ne kadar bu cümle tüm toplumsal yaşamın yeniden örgütlenmesi için kullanılacak materyalist ekonomi simülasyonunun eleştirisi için kurulmuş olsa da simgesel değiş tokuş düzenine bir amaç kazandırarak belirleyicilik sunma işlevine muhasebenin de hizmet ettiği belirtilebilir. Zira muhasebe sayesinde işletmelerin kıtalar arası farklı coğrafyalardaki faaliyetlerini kolaylaştıracak bir hesap dili geliştirilmiş olmaktadır. Uluslararası Muhasebe ve Finansal Raporlama Standartları/UMS-UFRS ile bu dil evrensel ve genel geçerli bir yapıya büründürülmektedir. Bu anlamda benzer şablonlar üzerinden hazırlanıp karşılaştırılabilen, kolay konsolide edilebilen bir raporlama çerçevesi geliştirilmeye çalışılmaktadır. Muhasebe sayesinde şeffaf ve hesap verebilir raporlarla yakınsanmış ve zamanla uyumlaştırılmış bir hesap dili konuşan işletmeler idealize edilmektedir. Söz konusu durum simülakrlar düzeninin son basamağını oluşturan kodların belirleyici olduğu simülasyon evresiyle de örtüşmektedir. Nitekim bu evrede Baudrillard (2011) mutlak bir denetimi hedefleyen simülasyon simülakrlarının varlığından da bahsetmektedir. Bilgi toplumunda işletmelerin tüm uygulama ve yönetim süreçleriyle mali olarak saydam ve hesap verebilir nitelikte olması hedefinin/ideal söyleminin raporlama fonksiyonu yoluyla büyük ölçüde muhasebeden beklendiği görülmektedir. Dolayısıyla 
muhasebe, kodların belirleyici olduğu son simülasyon evresinde mutlak denetim görevini yerine getiren simülakrlara alan açmaktadır.

Simülasyon, simülakrlar ve muhasebe ilişkisini ele alacak takip eden çalışmalarda söz konusu ilişkiye işaret edecek farklı örnekler çeşitlendirilebilir, Simülasyon Kuramı'nın muhasebedeki olası yansımaları sayısal analizlerle de belirlenmeye çalışılabilir. 
EXTENDED ABSTRACT

\section{The Relation with Accounting and Simulation Theory}

Ömer Yazan

Aksaray University

The Simulation Theory of Jean Baudrillard is evaluated as one of the most important theories about human sciences in the $20^{\text {th }}$ century. In this theory, Baudrillard (2014, p.13-14) defines simulation with derivation of truth through models that devoid of an origin or reality. He also describes simulacras as appearances that accepted as reality in the simulation world.

A relationship between Simulation Theory and human life and its actions can be established directly or indirectly. This relation can be predicted for accounting too. Thus some studies in the accounting literature (Macintosh, Shearer, Thornton \& Welker (2000), Macintosh (2002), Gårseth-Nesbakk (2011) Bougen \& Young (2012), Anwar \& Suryaningrum (2013), Boiral (2013) Corazza et al. (2017)) examined the relation with simulation, simulacra and accounting. Related literature evaluated this relationship with specific subjects generally.

In this study, this issue is associated with accounting's theoretical bases, basic assumptions, accounting transactions, reporting and auditing sides. This study has evaluated the relationship with regards to the development of simulacra order primarily. Copying, production and simulation, the three stages of simulacra order, correlated with the development of double-entry bookkeeping, intercontinental applicable accounting rules and electronic accounting information that leads economic decisions almost single-handedly. Then the relevant relationship between accounting and Simulation Theory has been evaluated by samples as the assumptions of Economic Entity and Going Concern, accounts receivable and bills receivable, rediscount operations, year-end valuation of operations with foreign currency, provisions, accrued income and expenses, 
depreciation operations, securities, derivative financial instruments, measurement of financial instrument with fair value, crypto currencies, sustainability and corporate social responsibility reports and auditing scandals. With this aspect, this study aims to provide a total approach to the relationship between Simulation Theory and accounting.

Accounting's assumption of economic entity describes that the business has a separate personality from its employers, share-holders, managers, personnel or other related persons/institutions and accounting also responsible for all of its transactions to this personality. This commercial personality that's one of the basic assumptions of modern accounting, is a kind of hyper real simulation character (economic entiy simulacra) with establishing the relationship of rights and obligations between everyone, using documents, accounts, books and statements of accounting

The going concern assumption of accounting accepts business as immortal unless otherwise stated. This assumption determines the real transactions of business but in fact, it is hyper real. Because business assumes its limited life like unlimited and this acknowledgement is considered as the basic reality of accounting. Accordingly the going concern assumption of accounting can be defined as simulacra (going concern simulacra).

Trade and other receivables (receivable simulacra) contain partly or wholly illusion of reality by considering their uncollectability in the date of maturity. With this aspect, rediscounting of bills receivables (rediscount simulacra) seems like simulacra of simulacra. A similar inference can be evaluated for bills payable and undocumented debts.

Year-end valuation of foreign exchange operations are a kind of simulacra (foreign exchange simulacra) because of their recognition as profit or loss in valuation date despite of unchanging into Turkish lira. Provisions for uncollectible receivables as well as their unascertainity in transaction date, and their reporting in income statement can be showed as an example of simulacra (provision simulacra). Operations of accruals that don't cause a change of entity, liability or equity in related period, just traceable in accounts, are examples of accounting's artificial realities (accruals simulacra). Depreciation transforms to a kind of accounting simulacra 
(depreciation simulacra) if there is a difference between impairment charges originating from usage and sum of reporting depreciation.

Equity shares are substantially influenceable from speculative movements and external effects and these entities are converted as an original goods rather than a security that represents company capital. With this aspect, equity shares can be evaluated as simulacra (equity share simulacra) like government and corporate bonds, treasury bills etc. trading in securities exchange. Financial derivatives that are transformed to an entity in financial markets, and their measurement and valuation transactions with fair value, create a simulative appearance (derivative simulacra). Crypto currencies, with no tangible structure and not being supported from a real entity, are creating by electronic codes but they are converted as an instrument of real goods' and services' exchange. Thus crypto currencies can be identified as modern simulacras (crypto simulacra) of current economic system.

Sustainability reports and corporate social responsibility/CSR reports that effect interest groups' perceptions and activities towards business with their favorable, environment-friendly and transparent appearance of business, are described as simulacras (sustainability simulacra, CSR simulacra). Auditing scandals in Enron, Global Crossing, Worldcom etc. can be considerated as a natural consequence of simulation with using accounting data. Because the information of financial statements that are the basis for economic decisions of interest groups, substitutes for reality and transforms as simulacra (auditing simulacra).

In the following studies, different examples related with the relationship between simulation, simulacra and accounting can be diversified and possible reflections of Simulation Theory on accounting can be determined with numerical analysis. 


\section{Kaynakça/References}

Akdoğan, N. ve Sevilengül, O. (2007). Türkiye muhasebe standartlarn ile uyumlu tekdüzen muhasebe sistemi uygulaması. 12. Baskı, Gazi Kitabevi, Ankara.

Akgüç, Ö. (2009). Kriz nedeni ve çıkış yolları. Muhasebe ve Finansman Dergisi. 42. 6-11.

Anwar, S. and Suryaningrum, D. H. (2013). A baudrillarian view of accounting goodwill. Revrew of Business and Finance Studies. 4/1. 95-105.

Ayhan, B. (2009). Siyasal iktisat ve kurumsal sosyal sorumluluk. Yönetim Araştırmaları Dergisi, 9/2, 173-187.

Baudrillard, J. (2011). Simgesel değiş tokuş ve ölüm (Çev. O. Adanır). 3. Basım, Boğaziçi Üniversitesi Yayınevi, İstanbul.

Baudrillard, J. (2013). Üretimin aynası ya da tarihi materyalist eleştiri yanılsamasl (Çev. O. Adanır). Boğaziçi Üniversitesi Yayınevi, İstanbul.

Baudrillard, J. (2014). Simülakrlar ve simulasyon (Çev. O. Adanır). 9. Basım, Doğu Batı Yayınları, Ankara.

Boiral, O. (2013). Sustainability reports as simulacra? a counter-account of a and a+ gr1 reports. Accounting, Auditing \& Accountability Journal, 26/7, 1036-1071.

Bougen, P.D. and Young, J.J. (2012). Fair value accounting: simulacra and simulation. Critical Perspectives on Accounting, 23, 390- 402.

British Petroleum/BP. (2009). Sustainability Review. https://www.bp.com/content/dam/bp/pdf/sustainability/group-reports/bp_sustainability_review_2009.pdf. (25.08.2018).

Carvalho, J. M., Conde, M. and Nunes, R.M.C. (2003), The historical evalution of the portuguese management accounting literature. The Third Accounting History International Congress, Siena/Italy,http://citeseerx.ist.psu.edu/viewdoc/download?doi=10.1.1.2 03.4282\&rep=rep1\&type $=$ pdf (28.04.2018).

Catalo, M. and Girlando-Azema N. (2012). Lady accounting, and analogy using blood circulation to popularise an accounting view of the health of the firm. (Ed: Y. Levant, O. de la Villarmois). French Accounting History New Contribitions, Taylor\&Francis, New York. 
Corazza, L., Scagnelli, S.D. and Mio, C. (2017). Simulacra and sustainability disclosure: analysis of the interpretative models of creating shared value. Corporate Social Responsibility and Environmental Management, $24,414-434$.

Degrange, M. E. (1818). La tenue des livres rendue facile, ou nouvelle methode d'enseignement. Crez Saintin- Libraire, Dixieme Edition, Paris.

Fleming, P. and Jones, M.T. (2013). The End of Corporate Social ResponsibilityCrisis and Critique. SAGE Publications Limited, London, UK.

Gårseth-Nesbakk, L. (2011). Accrual accounting representations in the public sector-a case of autopoiesis. Critical Perspectives on Accounting, 22, 247-258.

Güzel, M. (2015). Gerçeklik ilkesinin yitimi: baudrillard'ın simülasyon teorisi'nin temel kavramları, Felsefe ve Sosyal Bilimler Dergisi, 19, 65-84.

Hofman, A.J. and Jennigs, P.D. (2011). The BP oil spill as a cultural anomaly? institutional context, conflict and change. Journal of Management Inquiry, 20/2, 100-112.

İktisadi Devlet Teşekkülleri Yeniden Düzenleme Komisyonu/IDTYDK. (1968). Muhasebenin temel kavramları ve genel kabul görmüş muhasebe prensipleri. Başbakanlık Basımevi, Ankara.

İstanbul Serbest Muhasebeci Mali Müşavirler Odası/İSMMMO. (2006). Muhasebenin temel kavramları ve tekdüzen hesap planı. İSMMMO Mevzuat Serisi 2. Mart Matbaacilık Sanatları Tic. ve San. Ltd. Şti. İstanbul.

Kamu Gözetimi Muhasebe ve Denetim Standartları Kurumu/KGK. (2014). TMS 16 maddi duran varliklar. http://www.kgk.gov.tr/Portal v2Uploads/files/DynamicContentFiles/T\%C3\%BCrkiye\%20Muhase be $\% 20$ Standartlar\%C4\%B1/TMSTFRS2016Seti/ TMS16.pdf (18.08.2018).

Kamu Gözetimi Muhasebe ve Denetim Standartları Kurumu/KGK. (2017). Türkiye denetim standartlarl, bağımsız denetim standardı 570 işletmenin sürekliliği. http://kgk.gov.tr/Portalv2Uploads/ files/Duyurular/v2/BDS/bdsyeni25.12.2017/BDS\%20570-Site.pdf (02.08.2018).

Kamu Gözetimi Muhasebe ve Denetim Standartları Kurumu/KGK. (2018a). TMS 1 finansal tablolarm sunuluşu. http://kgk.gov.tr/Portalv2 Uploads/files/Duyurular/v2/TMS/TMS\%201\%20Finansal \%20Tablolar\%C4\%B1n\%20Sunulu\%C5\%9Fu.pdf (01.08.2018). 
Kamu Gözetimi Muhasebe ve Denetim Standartları Kurumu/KGK. (2018b). TFRS 13 Gerçeğe uygun değer ölçümü, http://www.kgk.gov.tr/Portalv2Uploads/files/DynamicContentFiles/T\%C3\%BCrkiye\%20Muhasebe\%20Standartlar\%C4\%B1/TMSTFRS2018Seti/TFRS/TF RS_13_2018.pdf (20.08.2018).

Kayahan, C. (2009). Finansal türevler: efsaneleri ve algılanma hataları. Yönetim ve Ekonomi Dergisi, 16/1, 23-37.

Macintosh, N.B. (2002). A linguiistic approach to understanding accounting: a "wild card" possibility. Working Paper, Queen's University, Kingston, Canada, http://citeseerx.ist.psu.edu/viewdoc/ download?doi=10.1.1.472.848\&rep=rep1\&type=pdf (09.07.2018).

Macintosh, N.B, Shearer, T., Thornton, D.B., Welker, M. (2000). Accounting as simulacrum and hyperreality: perspectives on income and capital. Accounting, Organizations and Society, 25, 13-50.

Macintosh, N.B. and Shearer, T. (2000). The accountıng profession today: a poststructuralist critique. Critical Perspectives on Accounting, 11, 607626.

Marian, O. (2013). Are cryptocurrencies super tax havens? Michigan Law Review First Impressions, 112, 38-48.

Mattessich, R. (2003). Accounting representation and the onion model of reality: a comparison with baudrillard's orders of simulacra and his hyperreality. Accounting, Organizations and Society, 28, 443-470.

Memiş, T. (2012). Şirketler hukukunda denetim. Erzincan Üniversitesi Hukuk Fakültesi Dergisi, 16, 3/4, 151-186.

Nihad, S. (1916), Defter-i kebirli yeomiye yahud amerikan usulü. Matbaa-i Amire, İstanbul.

Perez, J. M. R. (1826), La teneduria de libros simplificada o, nuevo método de enseñanza. En La Imprenta De Don Pedro Beaume, Burdzos.

Şımga-Mugan, F.N.C. ve Hacıhasanoğlu, E. (2010). Gerçeğe uygun değer ve kriz: tartısmalı ilişki. Management and Administration Research Center, METU, MARC Working Paper Series, Working Paper No. 2010-01.

Topbaş, N. (2009). Finansal kriz ortaminda bankalarin muhasebe sistemlerinde gerçeğe uygun değerleme yönteminin etkileri. Bankacılık Dergisi, 68, 56-64.

Verdinois, A. (1837). La tenuta dei libri resa facile, ovvero nuovo metodo d'insegnamento. Dalla Tipografia Del Vesuvio, Napoli. 
http://www.tdk.gov.tr/index.php?option=com_gts\&arama=gts\&kelime=t\% C3\%B6z\&uid=52302\&guid=TDK.GTS.5874ea13dc9d93.18916879 (29.09.2018)

\section{Kaynakça Bilgisi / Citation Information}

Yazan, Ö. (2018). Muhasebe ve simülasyon kuramı ilişkisi. OPUSUluslararası Toplum Araştırmaları Dergisi, 9(16), 1114-1142. DOI: 10.26466/opus. 461551 